\title{
Fungal-Mediated Biotransformation of Soybean Supplemented with Different Cereal Grains into a Functional Compound with Antioxidant, Anti- Inflammatory and Antitumoral Activities
}

Fernanda Guilherme do Prado ${ }^{1}$ (D), Mitiyo Fukuda Miyaoka ${ }^{1}$ (D), Gilberto Vinícius de Melo Pereira ${ }^{1}$ (D), Maria Giovana Binder Pagnoncelli ${ }^{2}$ (D), Maria Rosa Machado Prado ${ }^{3}$ (D), Sandro José Ribeiro Bonatto ${ }^{\text {(D) }}$, Michele Rigon Spier ${ }^{5}$ (D), Carlos Ricardo Soccol 1,* (D)

1 Department of Bioprocess Engineering and Biotechnology, Federal University of Paraná, Curitiba, PR, Brazil; fernanda.gprado@outlook.com (F.G.P); mitiyomiyaoka@ufpr.br (M.F.M); gilbertovinicius@gmail.com (G.V.M.P); soccol@ufpr.br (C.R.S);

2 Department of Chemistry and Biology, Federal University of Technology - Paraná (UTFPR), Curitiba, PR, Brazil; giobinder@gmail.com (M.G.B.P);

3 Faculdades Pequeno Príncipe, Curitiba, PR, Brazil; mrosaprado@ hotmail.com (M.R.M.P)

4 Pelé Pequeno Príncipe Research Institute, Curitiba, PR, Brazil; sandrobonatto@ gmail.com (S.J.R.B);

5 Department of Chemical Engineering, Federal University of Paraná, Curitiba-PR, Brazil; spier@ufpr.br (M.R.S);

* Correspondence: soccol@ufpr.br (C.R.S);

Received: 3.06.2020; Revised: 5.07.2020; Accepted: 6.07.2020; Published: 9.07.2020

\begin{abstract}
The aim of this study was to select fungal strains and alternative substrates to increase the production of bioactive compounds by solid-state bioprocessing using soybeans. Initially, from a total of 17 fungi strains, $R$. oligosporus NRRL 3267, R. oligosporus NRRL 2710, and $R$. arrhizus NRRL 2582 were pre-selected for presenting the greatest antioxidant activities during soybean fermentation. The three Rhizopus strains were cultured in soybeans supplemented with different cereal grains (brown rice, wheat, corn, and oat) aiming to achieve a higher antioxidant activity. Soybean supplementation with brown rice increased the concentration of phenolic compounds (0.697 to $6.447 \mathrm{mg}$ GAE g-1) significantly compared with the only use of soybean (1.792 to $\left.3.10 \mathrm{mg} \mathrm{GAE} \mathrm{g}^{-1}\right)$, using $R$. oligosporus NRRL 2710. The improved fungal-mediated biotransformation process ( $R$. oligosporus NRRL 2710 with soybeans and brown rice) generated an isoflavone aglycone-rich product, containing different antioxidant compounds, such as trans-cinnamic acid, gallic acid, myricetin, quercetin, and kaempferol. The fermented substrate also showed great potential to inhibit hyaluronidase enzyme (antiinflammatory activity) and against CaCo-2 tumor cells growth (antitumor activity). The resulting compound could serve as a value-added food and/or feed ingredient and a rich source of bioactive compounds.
\end{abstract}

Keywords: fermentation; antioxidants; anti-inflammatory; polyphenolic compounds; trans-cinnamic acid; Rhizopus sp.

(C) 2020 by the authors. This article is an open-access article distributed under the terms and conditions of the Creative Commons Attribution (CC BY) license (https://creativecommons.org/licenses/by/4.0/).

\section{Introduction}

Antioxidants are among the main health components that consumers expect in their food products, due to beneficial effects in the prevention of many diseases caused by oxidative cell processes and species oxygen-reactive, such as aging, cataracts, coronary heart diseases, 
arteriosclerosis, arthritis, diabetes and cancer [1-3]. Phenolic compounds are an important class of phytochemicals antioxidants. These compounds reach at least 8000 phenolics structures known to date [4], acting as reducing agents (free radical terminators) and metal chelates and singlet oxygen quenchers [5]. Extensively studied sources of natural antioxidants are fruits, vegetables, seeds, cereals, berries, wine, tea, onion bulbs, olive oil, coffee, and aromatic plants [6]. However, natural antioxidants can also be released via biotechnological processes by submerged or solid-state microbial fermentation. Solid-state fermentation (SSF) has some facilities related to the recovery of bioproducts and the use of natural substrates as nutritional support. Since 1986 in Brazil, a series of research projects for the value-addition of tropical agricultural products and sub-products by SSF has been developed due to the generation of large amounts of agricultural residues [7]. Then, in the last years, SSF has been employed to increase the content of phenolic compounds in certain food products, thus enhancing their antioxidant activity [8-10].

Soybean Glycine max L. Merrill is naturally known for presenting health benefits and high protein content. It has been successfully cultivated around the world and is largely produced by the world's top producers United States, Brazil, Argentina, China, and India. It is widely known that soybeans fermented by filamentous fungi possess enhanced nutritional value, such as antioxidants, vitamins, phytochemicals, and essential fatty acids [11-15]. Other agroindustrial grains are also good sources of antioxidants constituents but very little explored in fermentation processes $[16,17]$.

Soybeans are the richest sources of isoflavones (phytoestrogen compounds with estrogenic activity) in the human diet [18-20]. Isoflavones are divided into two basic phytochemical categories: glycosides and aglycones [21]. The aglycone forms are characterized by being more quickly absorbed by the organism and have the higher estrogenic and antioxidant potential $[22,23]$. The percentage of aglycones in non-fermented soybeans ranges between 10 and $40 \%$. In contrast, the percentage of aglycones in fermented soy products ranges between $40 \%$ and $100 \%[24,25]$. Thus, the consumption of fermented soy products in Eastern countries is associated with the reduction of chronic diseases, because the consumption of natural antioxidants is effective in reducing the deleterious effects of reactive oxygen species (ROS) and restoring the body's antioxidant load [26-29].

The aim of the present study was to select fungi strains and alternative substrates to increase the production of bioactive compounds by solid-state bioprocessing using soybean supplemented with different cereal grains, as well as to evaluate the anti-inflammatory and antitumor effects against $\mathrm{CaCo}-2$ and MCF-10 cells of the obtained substrate.

\section{Materials and Methods}

\subsection{Microorganisms.}

Seventeen fungi strains of the genus Rhizopus spp. (Figure 1) were used in this study, belonging for ARS Culture Collection of the Northern Regional Research Laboratory (NRRL, USA). The strains were maintained in Potato Dextrose Agar (PDA) slants at $4^{\circ} \mathrm{C}$.

\subsection{Substrate treatment.}

All the substrates used in this study (soybean, brown rice, wheat, corn, and oat) were pre-soaked in deionized water containing $5 \% \mathrm{v} / \mathrm{v}$ of acetic acid. After $12 \mathrm{~h}$, the substrates were 
thermally treated under fluent steam at $100^{\circ} \mathrm{C}$ for $15 \mathrm{~min}$. The excess water was removed, and the substrates cooled inoculation temperature of $30^{\circ} \mathrm{C}$.

\subsection{Selection of fungi strains.}

The fungal strains were pre-selected for antioxidant activity under SSF using soybean (SB) as a substrate. The substrate thermally treated was inoculated with $10^{7}$ spores per gram of dry matter. The experiments were carried out in perforated trays at $30^{\circ} \mathrm{C}$ for $72 \mathrm{~h}$. At the end of the $72 \mathrm{~h}$ of fermentation, antioxidant activity was evaluated as described below. Nonfermented soybean was used as a control.

\subsection{Antioxidant activity in SB supplemented with different cereal grains.}

\subsubsection{Substrate selection.}

SB supplementation tests were performed with fungal strains presenting higher antioxidant activity, viz., R. oligosporus NRRL 3267, R. oligosporus NRRL 2710, and R. arrhizus NRRL 2582. The cereal grains were brown rice (BR), wheat (W), corn (C), and oat (O). Before supplementation, selected grains were prepared by a thermal treatment, as previously described. Five experiments were conducted supplementing the SB by the grains in the proportion of $1: 1$ and inoculated with $10^{7}$ Rhizopus spp. spores $\mathrm{g}^{-1}$ of a dry substrate. The experiments were carried out in perforated trays at $30^{\circ} \mathrm{C}$ for $72 \mathrm{~h}$. The antioxidant activity of supplemented treatments was assessed, and non-fermented soybean was used as a control.

\subsubsection{Rhizopus selection.}

The kinetic behavior of the best treatments ( $\mathrm{SB}+\mathrm{BR}$ fermented by $R$. oligosporus NRRL 2710 or $R$. arrhizus NRRL 3267) was evaluated through $120 \mathrm{~h}$ of the fermentation process. Samples were taken at an interval of $24 \mathrm{~h}$ for antioxidant activity and phenolic content determination, as described below. From these results, $R$. oligosporus NRRL 2710 was selected for further characterization of isoflavone content and $\beta$-glucosidase, anti-inflammatory and antitumor activities.

\subsection{Analytical procedures.}

\subsubsection{Preparation of ethanol extracts.}

Alcoholic extraction of fermented substrates and control (non-fermented soybean) was performed according to the method described by [30]. A 1-g freeze-dried sample was crushed in a kitchen blender (Turbo Blender) for 5 min. Dry powder was extracted with $70 \%(\mathrm{v} / \mathrm{v})$ for one hour in a shaking water bath at $120 \mathrm{rev} / \mathrm{min}$. The extracts were collected and centrifuged at $2268 \mathrm{x} g$ for $15 \mathrm{~min}$. Supernatants were stored at $-18^{\circ} \mathrm{C}$ for further analysis.

\subsubsection{Measurement of DPPH radical-scavenging activity.}

The antioxidant activity of the alcoholic extracts was assessed based on the radical scavenging effect of the stable DPPH-free radical activity (1,1-diphenyl-2-picryhydarzyl) (Sigma-Aldrich, USA), as described by [31]. A methanol solution of DPPH $(0.004 \% \mathrm{w} / \mathrm{v})$ was prepared. BHA (butylated hydroxyanisole) (Sigma-Aldrich, USA) was used as a standard, prepared in concentrations from 0.02 to $1.00 \mathrm{mg}$ of BHA $\mathrm{mL}^{-1}$. One milliliter of the DPPH 
methanolic solution was added to $250 \mu \mathrm{L}$ sample extracts at different concentrations $(50 ; 100$;

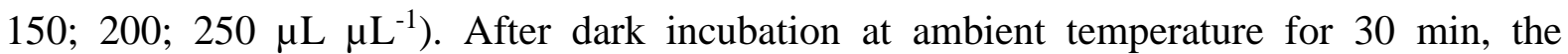
absorbance was measured at $517 \mathrm{~nm}$ (Spectrum band, UV-VIS). Ethanol solution without the sample was considered as a control. IC50 value (index representing the concentration of the antioxidant, which can reduce $50 \%$ of free radicals) was obtained using a standard curve. The inhibition rate $(\%)$ was calculated to the following equation:

Where:

$$
\text { inibition }(\%)=\left[\frac{A^{\text {control }}-A^{\text {extract }}}{A^{\text {control }}}\right] \times 100
$$

$\mathrm{A}^{\text {control }}=\mathrm{DPPH}$ absorbance (diluted with ethanol solution)

$\mathrm{A}^{\text {extract }}=\mathrm{DPPH}+$ sample extract absorbance (diluted with ethanol solution)

The percent antioxidant activity was plotted against log absorbance values to generate a straight line to calculate the half-inhibitory concentration ( $\left.\mathrm{IC}_{50}\right)$ in $\mathrm{mg} \mathrm{mL}^{-1}$. The anti-free radical activity (expressed as $\mathrm{IC}_{50}$ ) was defined as the quantity of antioxidant substances needed to reduce $50 \%$ of the initial concentration of DPPH. The higher the power anti-free radical, the most effective antioxidant, and, consequently, lower the IC50 value by [31].

\subsection{Determination of phenolic content.}

Total phenol content [32] was determined by the Folin-Ciocalteu method [33]. $0.1 \mathrm{~mL}$ of the alcoholic extracts was mixed with $0,4 \mathrm{~mL}$ of Folin-Ciocalteau reagent $(10 \% \mathrm{v} / \mathrm{v})$ and 0,4 $\mathrm{mL}$ of sodium carbonate $(7,5 \% \mathrm{w} / \mathrm{v})$. Samples, protected from light, were shaken by $1 \mathrm{~h}$. Ethanol was used as a control. The samples were analyzed in triplicate. A standard curve prepared using gallic acid monohydrate was used to calculate the total phenol content, which was expressed as gallic acid equivalent in $\mathrm{mg} \mathrm{L}^{-1}$ of the extract [34-36].

\subsection{Determination of $\beta$-glucosidase activity.}

$\beta$-glucosidase activity of ethanol extracts from $R$. oligosporus NRRL 2710 fermentation of $\mathrm{SB}+\mathrm{BR}(0,24,48$ and $72 \mathrm{~h})$ was assayed by monitoring the release of p-nitrophenol (pNP) using p-Nitrophenyl- $\beta$-D-glucopyranoside (pNPG) as the substrate, according to the method described by Zhang et al., 2012. A total of $20 \mu \mathrm{l}$ of appropriately diluted enzyme solution and $280 \mu \mathrm{l}$ of $1.785 \mathrm{mM}$ pNPG in $100 \mathrm{mM}$ acetate buffer $\mathrm{pH} 4.8$ were incubated for $15 \mathrm{~min}$ at 50 ${ }^{\circ} \mathrm{C}$. The reaction was quenched by adding $400 \mu \mathrm{l}$ of glycine buffer, and the amount of $\rho$ nitrophenol released during the reaction was determined with a spectrophotometer at $430 \mathrm{~nm}$. A $\rho$-nitrophenol calibration curve was previously prepared to calculate the enzyme activity. One unit of $\beta$-glucosidase activity was defined as the amount of enzyme equivalent to the release of $1 \mu \mathrm{mol}$ of $\mathrm{p}$-nitrophenol per minute.

\subsection{HPLC analysis of isoflavone.}

The ethanol extracts from $R$. oligosporus NRRL 2710 fermentation of SB + BR $(0,24$, 48 , and $72 \mathrm{~h}$ ) were filtered with a Spritzen syringe filter of $0.22 \mu \mathrm{m}$ (Millipore, Bedford, MA). Isoflavones content was analyzed using an Agilent Technology 1200 Series system, coupled to a diode array detector (DAD) at wavelengths 235, 260, 275, 280, 290, 311, 357, $370 \mathrm{~nm}$ and scanning from $190 \mathrm{~nm}$ to $600 \mathrm{~nm}$. A Zorbax Elipse XDB - C 18 (4.6 x $150 \mathrm{~mm}, 5$ - micron) column was used at $0.7 \mathrm{~mL}$ min-1 flow. The mobile phase utilized as methanol and acetic acid $2.5 \%(50: 50 \mathrm{v} / \mathrm{v})$. Genistein and daidzein (SIGMA Aldrich, EUA) were used as standards. To 
obtain the calibration curve, all standard reagents were solved in the mobile phase and used at $1,2,5,8$, and $10 \mathrm{ppm}$. The injection volume was $10 \mu \mathrm{L}$, and the run time was $36 \mathrm{~min}$. The resulting chromatograms values were graphed, and the linear equation was used to calculate the isoflavones content of the samples.

\subsection{Identification and quantification of antioxidant compounds by RP-HPLC-DAD/UV.}

The ethanol extracts from $R$. oligosporus NRRL 2710 fermentation of SB + BR (0, 48, and $72 \mathrm{~h}$ ) were filtered with a Spritzen syringe filter of $0.22 \mu \mathrm{m}$ (Millipore, Bedford, MA). The filtrate was used to quantify the polyphenolic compounds by High-performance liquid chromatography with UV-vis detection (HPLC-DAD/UV-vis). HPLC analysis was performed according to [37], with a reversed-phase Acclaim ${ }^{\circledR} 120$ column, $C 185 \mu \mathrm{m} 120 \AA(4.6 \mathrm{~mm} \times 250$ $\mathrm{mm}$ ). The column was maintained at $40^{\circ} \mathrm{C}$, and the detection was recorded at 280,300 , and $320 \mathrm{~nm}$. Polyphenolics and flavonols were detected in the range of 210 and $320 \mathrm{~nm}$. The mobile phase was acidified water with phosphoric acid $1 \%$ and methanol. The solvent gradient was as follows: $0-15 \% \mathrm{~B}$ for $2 \mathrm{~min}, 15-25 \%$ B for $5 \mathrm{~min}, 25-30 \% \mathrm{~B}$ for $10 \mathrm{~min}, 30-35 \%$ B for $15 \mathrm{~min}, 35-50 \%$ B for $25 \mathrm{~min}, 50-60 \%$ B for $30 \mathrm{~min}, 60-80 \%$ B for $35 \mathrm{~min}, 80-100 \% \mathrm{~B}$

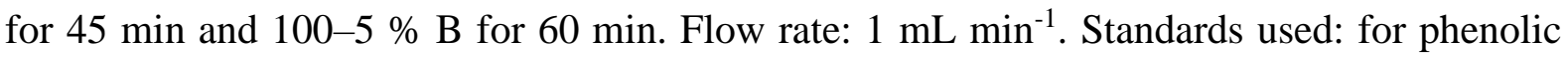
acids (gallic acid, chlorogenic acid, trans-cinnamic acid, caffeic acid, p-coumaric acid, ferulic acid) and flavonols (rutin, myricetin, quercetin, and kaempferol). Stock solutions of all standards were prepared in methanol. The calibration curves were obtained from triplicate injections of at least five concentrations and identification based on the retention times of the standards [38] in chromatogram at $280 \mathrm{~nm}$. Retention times (min) for the standards at the conditions used were: gallic acid: $6.83 \mathrm{~min}$; caffeic acid: $32 \mathrm{~min}$; p-cumaric acid: $18.54 \mathrm{~min}$; ferulic acid: 20.07 min; rutin: 25.03 min; myricetin: $28.22 \mathrm{~min}$; trans-cinnamic acid: $32.40 \mathrm{~min}$; kaempferol: $37.08 \mathrm{~min}$.

\subsection{In vitro evaluation of the anti-inflammatory activity.}

The anti-inflammatory activity of the substrate obtained by R. oligosporus NRRL 2710 fermentation of SB + BR was evaluated by the in vitro approach, according to [39], [40] and [41]. $50 \mu \mathrm{L}$ of the extracted ethanolic extracts were prepared at different concentrations $(1,3$, $10,30,100,300 \mu \mathrm{g} \mathrm{mL}^{-1}$ ) added to $0.5 \mathrm{~mL}$ of the potassium salt of hyaluronic acid (SigmaAldrich, St.Louis, MO, USA) (1.2 mg hyaluronic acid per $\mathrm{mL}$ of $0.1 \mathrm{M}$ acetate buffer, $\mathrm{pH} 3.6$, containing $0.15 \mathrm{M} \mathrm{NaCl}$ ). The control tube consisted of the same reagent of test tubes without ExPP. The reactions were incubated at $37^{\circ} \mathrm{C}$ for $5 \mathrm{~min}$. Then, $50 \mu \mathrm{L}$ of the hyaluronidase enzyme (Sigma-Aldrich, St.Louis, MO, USA) was added and incubated at $37{ }^{\circ} \mathrm{C}$ for $40 \mathrm{~min}$. The reaction was stopped by adding $10 \mu \mathrm{L}$ of sodium hydroxide $(4 \mathrm{~N})$ and immediately placing $0.1 \mathrm{~mL}$ of $0.8 \mathrm{M}$ potassium tetraborate and incubating in a boiling bath for $30 \mathrm{~min}$. After the incubation time, $3 \mathrm{~mL}$ of 4-dimethylaminobenzaldehyde (DMAB) (10\% solution in glacial acetic acid containing $12.5 \% 10 \mathrm{~N}$ hydrochloric acid) was added and incubated at $37{ }^{\circ} \mathrm{C}$ for $20 \mathrm{~min}$. Next, the absorbance of the solutions was measured in a spectrophotometer (SP 2000 UV Spectrum) at $585 \mathrm{~nm}$. DMSO was used as a positive control due to its ability to inhibit de hyaluronidase enzyme completely. Propolis, a natural anti-inflammatory agent, was also included as a positive control. The results were expressed as the ability to inhibit the hyaluronidase enzyme, in percentage. 
2.11. Cytotoxicity assessment for tumor (CaCo-2) and normal (MCF-10) cells by colorimetric assay MTT (1- (4,5-dimethylthiazol-2-yl) -2,5-diphenyl tetrazolium).

The cell lines $\mathrm{CaCo}-2$, which is Colorectal Cancer, and MCF-10 A, which is a nontumoral breast epithelial cell, were used to perform the assays with ethanol extracts from $R$. oligosporus NRRL 2710 fermentation of SB + BR. The ethanol extracts were first lyophilized for subsequent resuspension. Both cell lines were purchased from the Cell Bank of Rio de Janeiro, Brazil, passage 33. The lines were cultured in a 96-well plate in DMEM F12 medium with $1 \%$ penicillin/streptomycin for $24 \mathrm{~h}$ for cell adhesion. CaCo- 2 cells were plated at $5 \times 10^{4}$ cells per well and MCF 10A cells at the concentration of $3 \times 10^{4}$ cells per well. After the $24 \mathrm{~h}$ incubation period, the medium was monitored by DMEM F12 with 10\% penicillin/streptomycin and supplemented with $10 \%$ fetal bovine for both species. Plates were maintained in an incubator at $37^{\circ} \mathrm{C}, 95 \%$ air atmosphere and $5 \% \mathrm{CO}_{2}$ for $48 \mathrm{~h}$.

Cell viability was analyzed by colorimetric assay MTT (1- (4,5-dimethylthiazol-2-yl) 2,5-diphenyl tetrazolium), described by [42]. The MTT solution (Sigma-Aldrich) was prepared at the concentration of $5 \mathrm{mg} \mathrm{ml}^{-1}$ and added to the culture medium, where the final concentration in the well was $0.5 \mathrm{mg} \mathrm{ml}^{-1}$. After $3 \mathrm{~h}$ of incubation at $37^{\circ} \mathrm{C}, 95 \%$ air atmosphere, and $5 \% \mathrm{CO}_{2}$, the blue crystals formed were solubilized in DMSO (Panreac $\AA$ ), considered the most effective solvent to be capable of dissolving the formazan crystals easily. The reading was performed in a spectrophotometer (Biotek) at $595 \mathrm{~nm}$.

\subsection{Statistical analysis.}

Analysis results were submitted to the statistical variance, and the post-test was chosen according to the normality of the data obtained, such as Tukey Post-Test for data which follow normality. The program PRISMA® (GraphPad Prism 5 for Windows, version 5.4) was used. The averages of data are presented in graphs and the standard deviation shown by the error bars.

\section{Results and Discussion}

\subsection{Screening of Rhizopus strains.}

In Asiatic countries, Rhizopus spp. have been known as one of the economically important molds because of their role as an inoculum source for making tempeh, a traditional soybean-based fermented food $[11,13,43]$. In this study, a preliminary screening was carried out with 17 fungi strains of the genus Rhizopus based on their DPPH scavenging activity after $72 \mathrm{~h}$ of soybean under SSF. All Rhizopus strains presented positive results for antioxidant activity, i.e., they decreased IC50 values, which is a concentration of sample required to scavenge $50 \%$ of the DPPH (Figure 1a). Three strains, namely R. oligosporus NRRL 3267 (18.53 $\mathrm{mg} \mathrm{mL}^{-1}$ and $88.1 \% \pm 0.38$ for $\mathrm{IC}_{50}$ and scavening DPPH \%, respectively), $R$. oligosporus NRRL 2710 (20.49 $\mathrm{mg} \mathrm{mL}^{-1}$ and 85.7\% \pm 0.27 for $\mathrm{IC}_{50}$ and scavenging DPPH \%, respectively), and $R$. arrhizus NRRL 2582 (20.91 $\mathrm{mg} \mathrm{mL}^{-1}$ and 81.2\% \pm 0.31 for $\mathrm{IC}_{50}$ and scavenging DPPH $\%$, respectively), were pre-selected for possessing the best scavenging activities (Figure 1b). Other authors also reported good results of radical scavenging activity in fermented beans of Canavalia using Rhizopus microspores var. oligosporus (MTCC\#556) for 1 week [44] and Bacillus subtilis SB-MYP-1 for 72 h [14]. 

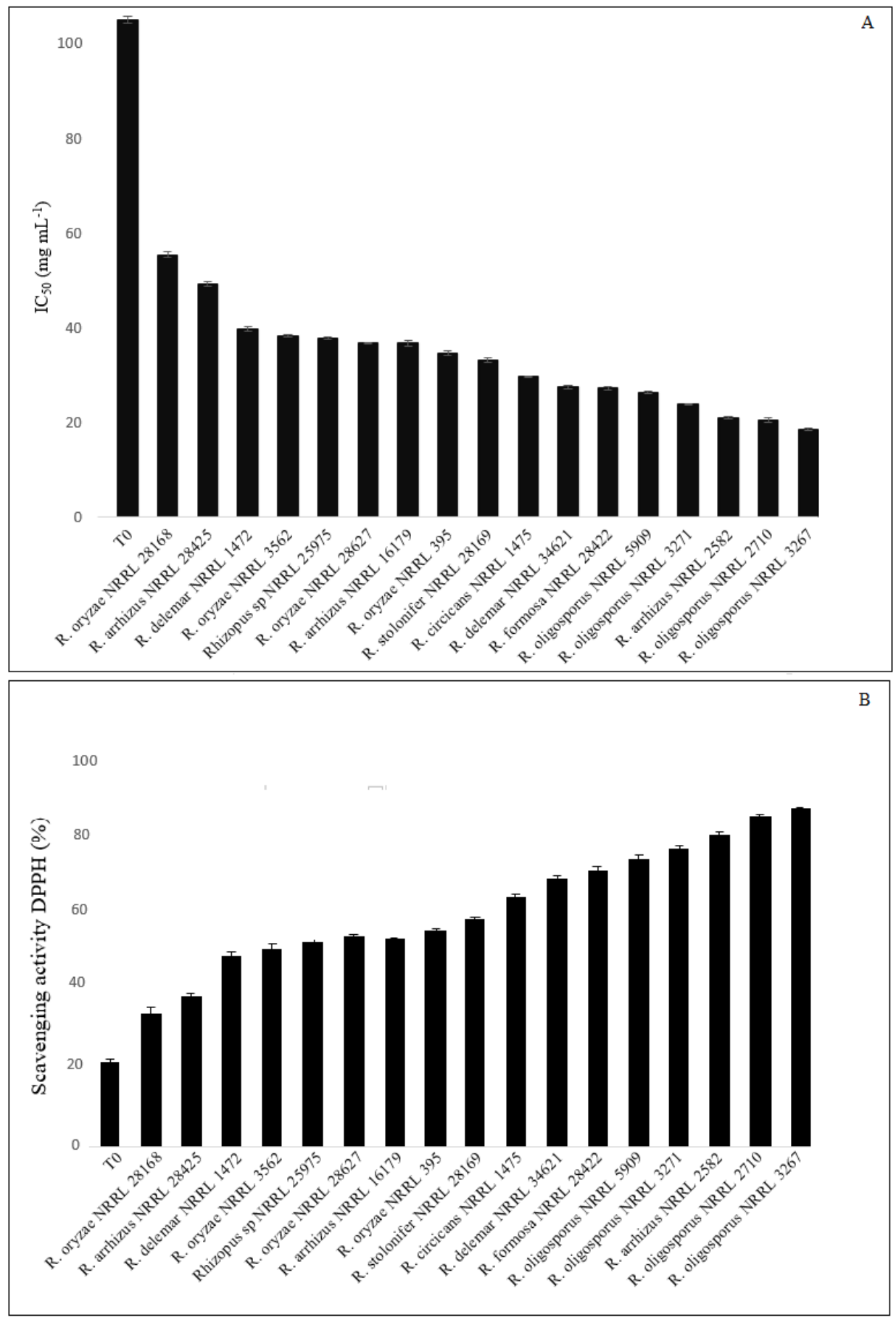

Figure 1 DPPH activity $\left(\mathrm{IC}_{50} \mathrm{mg} \mathrm{mL}^{-1}\right)(\mathbf{A})$ and scavenging DPPH \% (B) of the ethanolic extracts of different Rhizopus strains cultivated in soybeans by $72 \mathrm{~h}$.

\subsection{Substrate selection for antioxidant biosynthesis.}

The three pre-selected Rhizopus strains were cultured in soybeans supplemented with different cereal grains (brown rice, wheat, corn, and oat) aiming to achieve a higher antioxidant activity. All supplementation processes were efficient in increasing the antioxidant power of the substrate, as determined by the decrease of $\mathrm{IC}_{50}$ values after $72 \mathrm{~h}$ of fermentation (Table 1 ). The best results $(p<0.05)$ were achieved when SB was supplemented with BR by all strains analyzed. There is a lack of data in the literature on the real increase in scavenging activities due to the fermentation process. In general, existing studies do not assess scavenging activity at initial fermentation time, dedicating only to resulting products. As an example, [45] found 
$19.1 \mathrm{mg} \mathrm{mL}^{-1}$ scavenging activity of fermented soybean + rice by Aspergillus oryzae after 16 days for sufu production. However, the increment of the values during fermentation was not reported. The data of the present study clearly show the real increment in scavenging activities promoted by the fermentation process. SB supplementation with brown rice resulted in the greatest antioxidant potential for R. oligosporus NRRL 2710 (IC50 $14.3 \mathrm{mg} \mathrm{mL}^{-1}$ ), followed by $R$. arrhizus NRRL 2582 (IC50 $19.2 \mathrm{mg} \mathrm{mL}^{-1}$ ) and $R$. oligosporus NRRL 3267 (IC50 $33.7 \mathrm{mg}$ $\mathrm{mL}^{-1}$ ) (Table 1). For this reason, the SB supplemented with BR and fermented by $R$. oligosporus NRRL 2710 and R. arrhizus NRRL 2582 were selected for further studies. The choice of using $R$. oligosporus NRRL 2710 was also based on its wide use as a fermenting agent for Tempeh production [46].

Table 1. IC5 5 values $\left(\mathrm{mg} \mathrm{mL}^{-1}\right)$ during fermentation in SB ethanol extracts and grain mixtures at the started point $\left(\mathrm{T}_{0}\right)$ and after 72 hours of fermentation with the selected strains.

\begin{tabular}{|c|c|c|c|c|}
\hline & & $\begin{array}{l}\text { R. oligosporus } \\
\text { NRRL } 2710\end{array}$ & $\begin{array}{l}\text { R. oligosporus } \\
\text { NRRL } 3267\end{array}$ & $\begin{array}{l}R \text {. arrhizus } \\
\text { NRRL } 2582\end{array}$ \\
\hline \multirow[t]{2}{*}{ SB } & $\mathrm{T}_{0}$ & $105.01 \pm 0.62^{\mathrm{aA}}$ & $105.01 \pm 0.62^{\mathrm{aA}}$ & $105.01 \pm 0.62^{\mathrm{aA}}$ \\
\hline & $72 \mathrm{~h}$ & $20.69 \pm 0.27^{\mathrm{aA}}$ & $18.53 \pm 0.38^{\mathrm{aB}}$ & $20.90 \pm 0.31^{\mathrm{aA}}$ \\
\hline \multirow[t]{2}{*}{ SB + BR } & $\mathbf{T}_{\mathbf{0}}$ & $374.5 \pm 0.61^{\mathrm{dA}}$ & $374.5 \pm 0.61^{\mathrm{eA}}$ & $374.5 \pm 0.61^{\mathrm{eA}}$ \\
\hline & $72 \mathrm{~h}$ & $14.3 \pm 0.13^{\mathrm{aA}}$ & $33.7 \pm 0.51^{\text {bB }}$ & $19.2 \pm 0.31^{\mathrm{aA}}$ \\
\hline \multirow[t]{2}{*}{ SB + OAT } & $\mathrm{T}_{0}$ & $180.8 \pm 0.39^{\mathrm{bA}}$ & $180.8 \pm 0.39^{\mathrm{cA}}$ & $180.8 \pm 0.39^{\mathrm{cA}}$ \\
\hline & $72 \mathrm{~h}$ & $69.5 \pm 0,84^{\mathrm{bA}}$ & $131,9 \pm 1,15^{\mathrm{dB}}$ & $63,3 \pm 0,16^{\mathrm{cA}}$ \\
\hline \multirow[t]{2}{*}{$\mathbf{S B}+\mathbf{C}$} & $\mathrm{T}_{0}$ & $346.2 \pm 0.32^{\mathrm{cA}}$ & $346.2 \pm 0.32^{\mathrm{dA}}$ & $346.2 \pm 0.32^{\mathrm{dA}}$ \\
\hline & $72 \mathrm{~h}$ & $23,3 \pm 0,50^{\mathrm{aA}}$ & $32,93 \pm 0,59^{\mathrm{bB}}$ & $45,7 \pm 0,50^{\mathrm{bC}}$ \\
\hline \multirow[t]{2}{*}{$\mathbf{S B}+\mathbf{W}$} & $\mathrm{T}_{0}$ & $166.1 \pm 0.97^{\mathrm{abA}}$ & $166.1 \pm 0.97^{\mathrm{bA}}$ & $166.1 \pm 0.97^{\mathrm{bA}}$ \\
\hline & $72 \mathrm{~h}$ & $54.0 \pm 0.93^{\mathrm{bA}}$ & $76.6 \pm 0.31^{\mathrm{cB}}$ & $52.2 \pm 0.50^{\mathrm{cA}}$ \\
\hline
\end{tabular}

*Means followed by the same letter did not differ statistically ( $p>0.05$ ). Lowercase letters refer to the statistical test between the lines and capital letters between the columns.

3.3. Kinetic of fermentation with R. oligosporus NRRL 2710 and R. arrhizus NRRL 2582 in SB $+B R$.

Kinetics of scavenging activity ( $\mathrm{IC}_{50}$ ) and phenolic content were performed through 72h of SB+BR fermentation by $R$. oligosporus NRRL 2710 and $R$. arrhizus NRRL 2582 (Figure 2). For both strains, scavenging activity had a sharp decrease from 0 to $72 \mathrm{~h}$, followed by a stabilization until the end of the fermentation process (Figure 2a). The best antioxidant activity (indicated by the small $\mathrm{IC}_{50}$ value) was reached by $R$. oligosporus NRRL 2710 (14.1 $\mathrm{mg} \mathrm{mL} \mathrm{m}^{-1}$ ) in relation to $R$. arrhizus NRRL $2582\left(23.15 \mathrm{mg} \mathrm{mL}^{-1}\right)$. The content of phenolic compounds showed a progressive increase in the course of the fermentation (Figure $2 \mathrm{~b}$ ). Similarly, $R$. oligosporus NRRL 2710 reached the highest phenolic content ( $6.44 \mathrm{mg}$ and 3.81 mg GAEg ${ }^{-1}$ for $R$. oligosporus NRRL 2710 and $R$. arrhizus NRRL 2582, respectively). Thus, R. oligosporus NRRL 2710 was selected for further characterization.

\subsection{Identification and quantification of polyphenolic compounds.}

Table 2 shows the identification and respective concentrations of polyphenolic compounds synthesized by $R$. oligosporus NRRL 2710 under SSF of SB and SB+BR, as quantified by RP- HPLC-DAD/UV. Different polyphenolic compounds were detected, such as gallic acid, ferulic acid, rutin, myricetin, caffeic acid, trans-cinnamic acid, quercetin, kaempferol, syringic acid, and p-cumaric acid. These compounds have been previously found in SSF by different fungi species [47-50][47,48].

The data showed that trans-cinnamic acid was the compound present in higher amounts, reaching $124.7 \mu \mathrm{g} \mathrm{mL}^{-1}\left(3,197 \mathrm{mg} \mathrm{gdb}^{-1}\right)$ and $103.3 \mu \mathrm{g} \mathrm{mL}^{-1}\left(2,649 \mathrm{mg} \mathrm{gdb}^{-1}\right)$ in SB and SB+BR 
fermented after $72 \mathrm{~h}$, respectively. The cinnamic acid or trans-3-phenylacrylic acid is an important precursor of the biosynthesis of other important groups of polyphenolic compounds in the microorganism metabolism pathway. Cinnamic acid is biosynthesized by the enzyme phenylalanine ammonia-lyase (PAL), which converts the aminoacid phenylalanine in cinnamic acid. It is also a precursor to the sweetener aspartame via enzyme-catalyzed amination to phenylalanine.

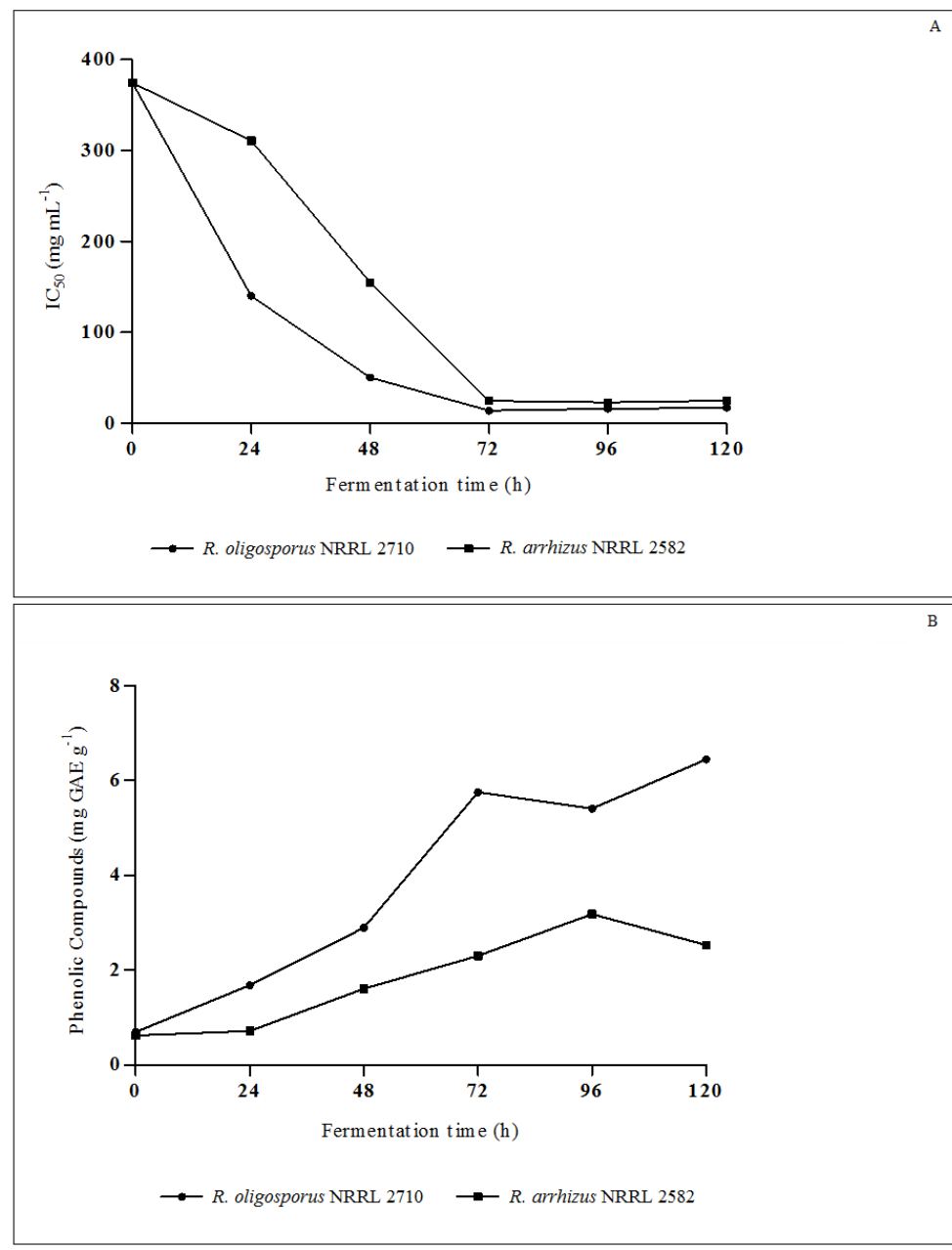

Figure 2. Kinetics of DPPH scavenging activity (A) and phenolics content (B) of the ethanolic extracts of $R$. oligosporus NRRL 2710 and $R$. arrhizus NRRL 2582 cultivated in soybean supplemented with brown rice by $72 \mathrm{~h}$.

Cinnamic acid has been studied as an antitumoral compound, which induces tumor cell differentiation by modulating the expression of genes implicated in tumor metastasis and immunogenicity in cultured human melanoma cells. There are few reports on cinnamic acid production by fermentation process [51]. This work indicates a great potential for producing this compound due to the high accumulation in the fermented substrate. The separation and concentration of cinnamic acid from SB +BR fermented by $R$. oligosporus NRRL 2710 represent a great perspective for application in food and supplement products.

Soy is a known source of isoflavones - a subclass of flavonoids with powerful antioxidant activity and linked to cancer prevention [52-53]. Soybeans contain more isoflavones in the glycoside form (daidzin and genistin) than aglycone form (daidzein and genistein). Fermentation of soybeans promotes the conversion of glycoside into aglycone isoflavones through the action of $\beta$-glucosidase produced by microorganisms $[54,55]$. While 
all isoflavones are absorbed into the mucosa of the small intestine, the aglycone form is absorbed in a greater rate and also has higher antioxidant activity than the glycoside form [56].

Table 2. Identification and quantification $\left(\mathrm{mg} \mathrm{gdb}^{-1}\right)$ of polyphenolic at the ethanolic extracts during SSF of SB mixture with BR synthesized by $R$. oligosporus NRRL 2710.

\begin{tabular}{|c|c|c|c|c|}
\hline \multirow{2}{*}{ Substrates } & \multirow{2}{*}{ 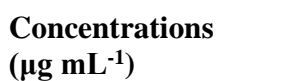 } & \multicolumn{3}{|c|}{ Fermentation time (h) } \\
\hline & & $\mathbf{0}$ & 48 & 72 \\
\hline \multirow{8}{*}{ SB } & Gallic acid & 0.2 & 0.0 & 0.0 \\
\hline & Ferrulic acid & 0.3 & 0.3 & 0.3 \\
\hline & Rutin & 29.3 & 6.1 & 8.7 \\
\hline & Miricetin & 9.8 & 6.9 & 7.4 \\
\hline & Caffeic acid & 0.0 & 0.0 & 0.0 \\
\hline & Trans-cinnamic acid & 0.0 & 93.4 & 124.7 \\
\hline & Quercetin & 0.0 & 0.0 & 0.2 \\
\hline & Kaempferol & 0.0 & 0.1 & 0.1 \\
\hline \multirow{10}{*}{$\mathrm{SB}+\mathrm{BR}$} & Gallic acid & 0.0 & 0.0 & 0.1 \\
\hline & Ferrulic acid & 0.1 & 0.2 & 0.2 \\
\hline & Rutin & 11.8 & 9.3 & 2.9 \\
\hline & Miricetin & 6.5 & 7.0 & 7.4 \\
\hline & Caffeic acid & 0.0 & 0.0 & 0.0 \\
\hline & Trans-cinnamic acid & 19.8 & 57.3 & 103.3 \\
\hline & Quercetin & 0.0 & 0.0 & 0.0 \\
\hline & Kaempferol & 0.0 & 0.0 & 0.1 \\
\hline & Siringic acid & 4.0 & 0.0 & 0.0 \\
\hline & p-cumaric acid & 0.1 & 0.0 & 0.0 \\
\hline
\end{tabular}

3.5. Changes in the isoflavone profile during fermentation of $S B+B R$ by Rhizopus oligosporus NRRL 2710.

Thus, it is more effective to obtain the benefits of ingesting isoflavones when in the aglycone than glycoside form [57]. In this study, the biotransformation of isoflavones during fermentation of SB+BR by Rhizopus oligosporus NRRL 2710 was studied using highperformance liquid chromatography (HPLC) and $\beta$-glucosidase activity using spectrophotometry (Figure 3). The concentrations of daidzein and genistein (aglycone form) in the final fermented product (18.65 $\pm 0.08 \mathrm{mg} \mathrm{g}^{-1}$ and $12.68 \pm 0.05 \mathrm{mg} \mathrm{g}^{-1}$, respectively) were 3.75 and 20.10 fold, respectively, compared to non-fermented soybeans.

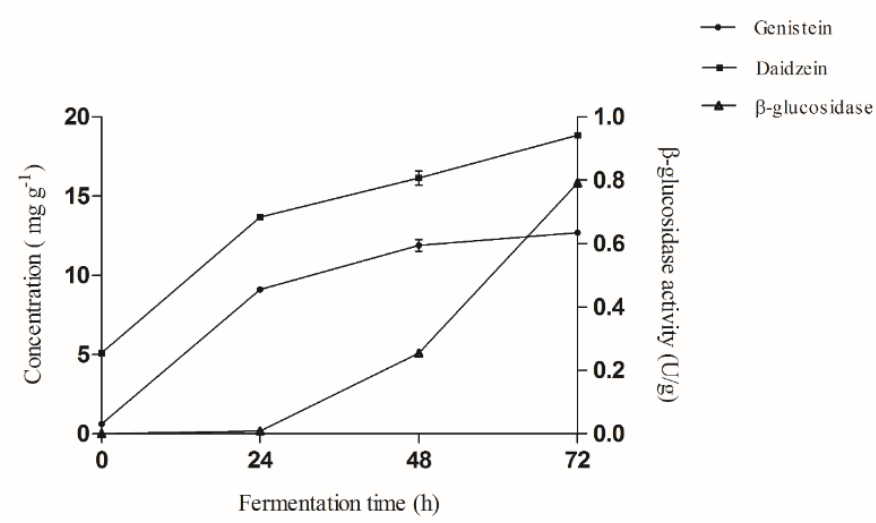

Figure 3. $\beta$-glucosidase activity and isoflavones aglycone content (daidzein and genistein) during soybeans plus brown rice fermentation by selected $R$. oligosporus NRRL 2710.

Simultaneously with the accumulation of aglycone isoflavones, $\beta$-glucosidase increased significantly after $24 \mathrm{~h}$ of fermentation (ranging from 0.01 to $0.81 \mathrm{U} / \mathrm{g}$ at the end of the process), is thus responsible for catalyzing aglycone isoflavones from glycine form. The values found in this study are significantly higher than those observed by [58] $\left(0.24 \mathrm{mg} \mathrm{g}^{-1}\right.$ and 
$0.043 \mathrm{mg} \mathrm{g}^{-1}$ for daidzein and genistein, respectively) after $72 \mathrm{~h}$ of soybean fermentation using Tricholoma matsutake, and by [24] (1.084 $\mathrm{mg} \mathrm{g}^{-1}$ and $1.810 \mathrm{mg} \mathrm{g}^{-1}$ of daidzein and genistein, respectively) after $72 \mathrm{~h}$ of okara fermentation with Saccharomyces cerevisiae.

\subsection{Anti-inflammatory activity.}

The anti-inflammatory activity of the R. oligosporus NRRL 2710 ethanolic extract was assessed by hyaluronidase inhibitory activity. The hyaluronidase enzyme acts on the extracellular matrix of the tissues, increasing the permeability, and facilitating the access of pathogens involved in inflammatory processes [59-61]. The results obtained are shown in Figure 4. The fermentation process increased hyaluronidase inhibitory activity 3.36 times when compared to unfermented soybeans $(70.75 \%$ and $21.03 \%$ inhibition capacity for fermented and unfermented soybeans, respectively). The fermented ethanolic extract also showed significantly higher activity than propolis, a commercial anti-inflammatory product [41] tested a group of 31 flavonoids against the bovine testicular hyaluronidase enzyme. The presence of double bond between carbons 2 and 3 of the fundamental nucleus of flavonoids was a fundamental condition for the compound to present hyaluronidase inhibitory activity; a keto group at position 4 and the introduction of 5, 7 and 4 ' hydroxyls showed to increase the effect of flavonoids [62]. However, the presence of glycosidic substituents decreased the inhibitory effect on the bovine testicular enzyme. The author concluded that aglycones forms of flavonoids are better inhibitors of hyaluronidase than their glycosylated derivatives. Thus, the improved fermentation process of $R$. oligosporus NRRL 2710 in SB + BR can have changed levels and forms of the isoflavones, promoting an increase in the aglycone content [63-65]. A dose-response analysis demonstrated that the ideal concentration value for inhibition to occur was $0.62 \mathrm{mg} \mathrm{mL}^{-1}$, in a $95 \%$ confidence interval (data not shown).

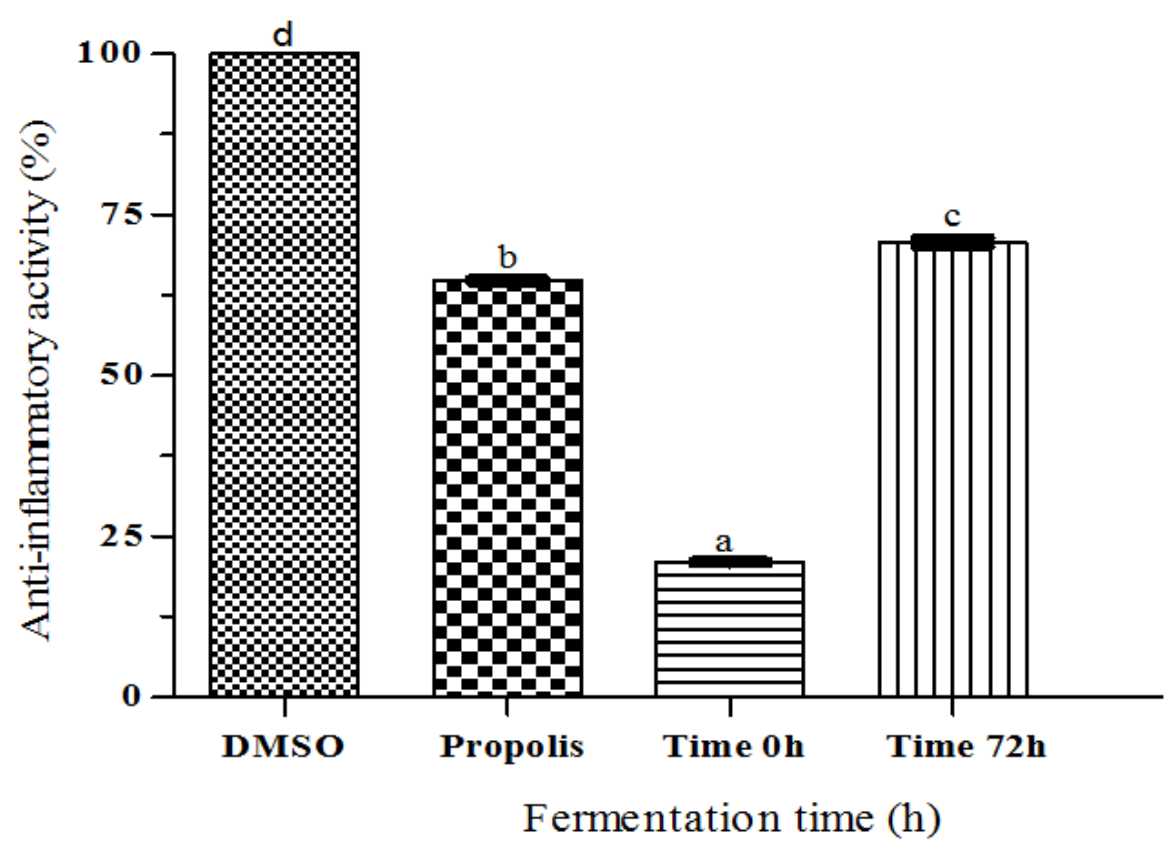

Figure 4. Anti-inflammatory activity of alcoholic extract of the $R$. oligosporus NRRL 2710 cultivated in soybean supplemented with brown rice by $72 \mathrm{~h}$.

*DMSO: positive control capable of completely inhibiting the enzyme hyaluronidase (HIA); Propolis: commercial anti-inflammatory 
3.7. Cytotoxicity assessment for tumor (CaCo-2) and normal (MCF-10) cells.

The values of cytotoxicity assessment for both unfermented soybeans $(0 \mathrm{~h})$ and fermented substrate (72 h) showed cytotoxicity for normal cells (MCF-10), as demonstrated by the decrease of viable cells at levels below 50\% (Figure 5A). However, ethanolic extracts from 48 and $72 \mathrm{~h}$ were considered moderately cytotoxic, with viable cells percentage values between 61.07 and $66.49 \%$, respectively. According to statistical analysis, these extracts presented no significant difference at the $95 \%$ level $(\mathrm{p}<0.05)$. Considering these results, a cell viability study was carried out with $\mathrm{CaCo}-2$ cancer cells to evaluate the cytotoxicity of the 72-h $R$. oligosporus NRRL 2710 fermented ethanolic extract at different concentrations (Figure 5B). The extracts presented a percentage of cellular viability between 39.53 and $46.89 \%$. The inhibitory concentration values (IC50) were $0.27 \mathrm{mg} \mathrm{mL}^{-1}$ for CaCo-2 cells and $0.79 \mathrm{mg} \mathrm{mL}^{-1}$ for normal MCF-10 cells, indicating a higher cytotoxic effect against the carcinogenic cell.

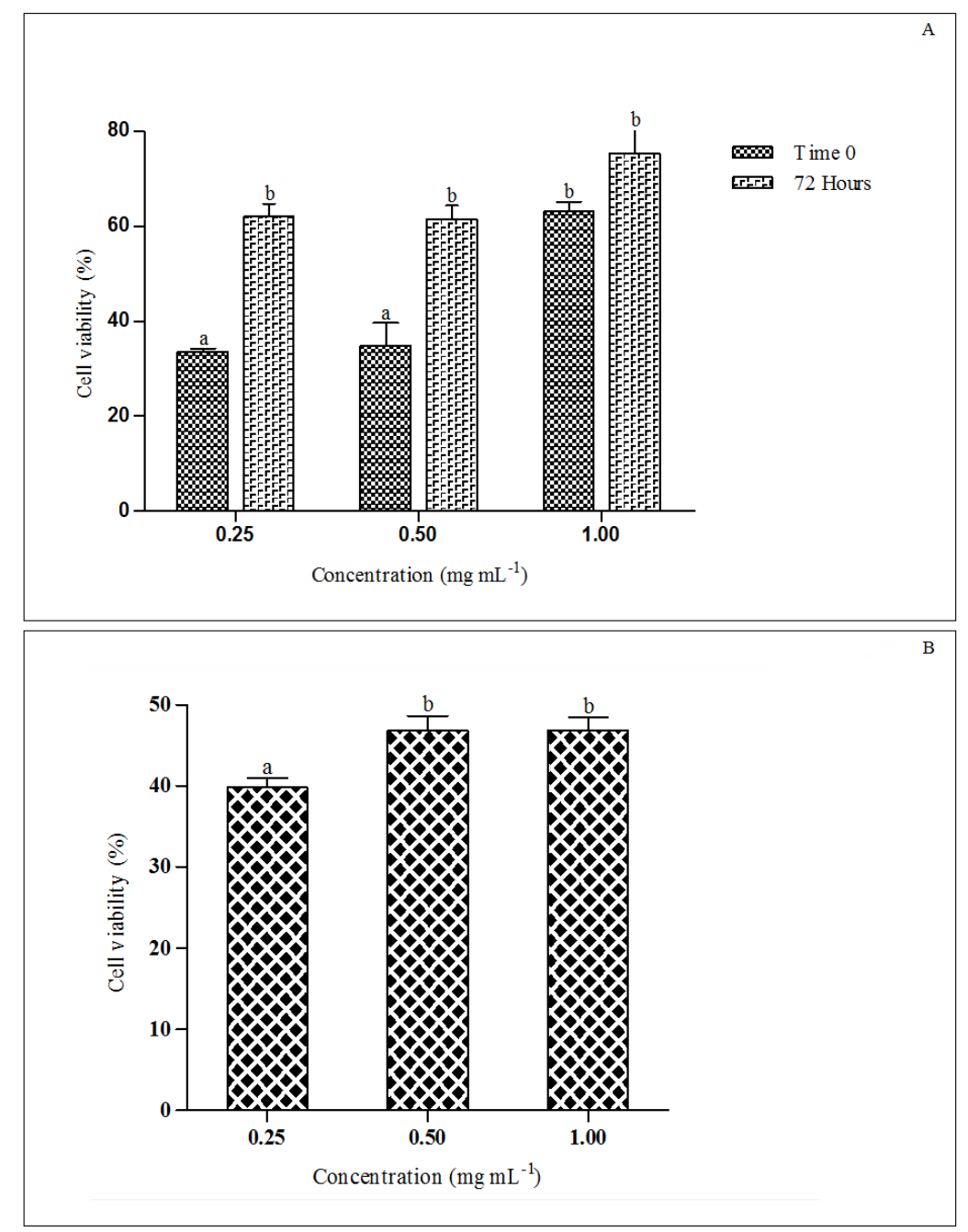

Figure 5. Cytotoxicity assessment of alcoholic extract of the R. oligosporus NRRL 2710 cultivated in soybean supplemented with brown rice against (A) normal cells (MCF-10) and (B) CaCo-2 tumor cells.

*The data represent the mean values \pm standard deviation of three independent experiments.

A lower percentage of cancer cell viability was observed at lower concentrations, showing that high concentrations are not required to attain cancer cell death. According to the statistical analysis, the extracts at different processing times showed a significant difference at the 95\% level ( $\mathrm{p}<0.05$ ), suggesting that the R. oligosporus NRRL $2710 \mathrm{SB}+\mathrm{BR}$ fermentation process was efficient; the lower value of cell viability of the cancer cells was obtained after 72 $\mathrm{h}$ of fermentation (39.53\%). According to [66] the variability of the results can be explained 
due to the presence of isoflavones and other phenolic compounds. Several studies show the inverse association between the consumption of soy products and the risk of degenerative diseases, such as cancer [68, 68]. The chemopreventive effects of soy are attributed to its bioactive molecules, such as isoflavones, which interact with the metabolic pathways responsible for controlling cell growth, proliferation, and differentiation [69-72].

\section{Conclusions}

This study reported that the selection of alternative substrates and fungal strains is an important strategy to improve the biosynthesis of antioxidant compounds by SSF. Soybean supplementation with brown rice increased the scanning activity significantly compared to the exclusive use of soybean, by $R$. oligosporus NRRL 2710 and $R$. arrhizus NRRL 2582 after 72 $\mathrm{h}$ of fermentation. This study demonstrated that the fermentation process was effective in the accumulation of myricetin, gallic acid, ferulic acid, kaempferol, and increased accumulation of trans-cinnamic acid. The fermented substrate could be processed as a new flour to be applied as a nutritional complement or as a food ingredient and dietary supplement with high antioxidant properties. In addition, this novel fermentation process points out to accumulation of cinnamic acid, which can be used as a novel, alternative way for the production of this antitumor compound. The actions are shown with in vitro anti-inflammatory, and antitumor models were effective. Further in vivo studies should be performed for the specification of these biologically active principles.

\section{Funding}

This research received no external funding.

\section{Acknowledgments}

The authors are grateful to CNPq (National Council for Scientific and Technological Development, Brazil) by the financial support and to CAPES (Coordination of Improvement of Higher Education Personnel, Brazil) by the scholarship.

\section{Conflicts of Interest}

The authors declare no conflict of interest.

\section{References}

1. Melo, E.A.; Maciel, M.I.S.; Lima, V.L.A.G.; Leal, F.L.L.; Caetano, A.C.S.; Nascimento, R.J. Capacidade antioxidante de hortaliças usualmente consumidas. Ciência e Tecnol Aliment 2006, 26, 639-644, https://doi.org/10.1590/S0101-20612006000300024.

2. Mukhopadhyay, A.K. Antioxidants-natural and Synthetic. Amani Int'l Publishers 2006.

3. Prior, R.L.; Cao, G.; Martin, A.; Sofic, E.; McEwen, J.; O’Brien, C.; Lischner, N.; Ehlenfeldt, M.; Kalt, W.; Kreer, G.; Mainland, C.M. Antioxidant Capacity As Influenced by Total Phenolic and Anthocyanin Content, Maturity, and Variety of Vaccinium Species. J Agric Food Chem 1998, 46, 2686-2693, https://doi.org/10.1021/jf980145d.

4. Bravo, L. Polyphenols: Chemistry, Dietary Sources, Metabolism, and Nutritional Significance. Nutr Rev 1998, 56, 317-333, https://doi.org/10.1111/j.1753-4887.1998.tb01670.x.

5. Alu'datt, M.H.; Rababah, T.; Ereifej, K.; Alli, I. Distribution, antioxidant and characterisation of phenolic compounds in soybeans, flaxseed and olives. Food Chem 2013, 139, 93-99, https://doi.org/10.1016/j.foodchem.2012.12.061.

6. Dimitrios, B. Sources of natural phenolic antioxidants. Trends Food Sci Technol 2006, 17, 505-512, https://doi.org/10.1016/j.tifs.2006.04.004. 
7. Soccol, C.R.; Vandenberghe, L.P.S. Overview of applied solid-state fermentation in Brazil. Biochem Eng J 2003, 13, 205-218, https://doi.org/10.1016/S1369-703X(02)00133-X.

8. Choung, M.G.; Baek, I.Y.; Kang, S.T.; Han, W.Y.; Shin, D.C.; Moon, H.P.; Kang, K.H. Isolation and determination of anthocyanins in seed coats of black soybean (Glycine max (L.) Merr.). J Agric Food Chem 2001, 49, 5848-5851, https://doi.org/10.1021/jf010550w.

9. Martins, S.; Mussatto, S.I.; Martínez-Avila, G.; Montañez-Saenz, J.; Aguilar, C.N.; Teixeira, J.A. Bioactive phenolic compounds: Production and extraction by solid-state fermentation. A review. Biotechnol Adv 2011, 29, 365-373, https://doi.org/10.1016/j.biotechadv.2011.01.008.

10. Zhao, Y.; Sun-Waterhouse, D.; Zhao, M.; Zhao, Q. Effects of solid-state fermentation and proteolytic hydrolysis on defatted soybean meal. LWT-Food Sci Technol 2018, 97, 496-502, https://doi.org/10.1016/j.lwt.2018.06.008.

11. Astuti, M.; Meliala, A.; Dalais, F.S.; Wahlqvist, M.L. Tempeh, a nutritious and healthy food from Indonesia. Asia Pac J Clin Nutr 2000, 9, 322-325, https://doi.org/10.1046/j.1440-6047.2000.00176.x.

12. Dinesh, B.P.; Bhakyaraj, R.; Vidhyalakshmi, R. A Low Cost Nutritious Food \&quot; Tempeh \&quot; -A Review. World J Dairy Food Sci 2009, 4, 22-27.

13. Hesseltine, C.W. Microbiology of Oriental Fermented Foods. Annu Rev Microbiol 1983, 37, 575-601, https://doi.org/10.1146/annurev.mi.37.100183.003043.

14. Samruan, W.; Oonsivilai, A.; Oonsivilai, R.; Soybean and Fermented Soybean Extract Antioxidant Activities. World Acad Sci Eng Technol 2012, 6, 1223-1226, https://doi.org/10.5281/zenodo.1081719.

15. Li, W.F.; Yang, K.; Zhu, P.; Zhao, H.Q.; Song, Y.H.; Liu, K.C.; Huang, W.F. Effect of solid-state fermentation with Lactobacillus casei on the nutritional value, isoflavones, phenolic acids and antioxidant activity of whole soybean flour. LWT-Food Sci Technol 2020, 125, https://doi.org/10.1016/j.lwt.2020.109264.

16. Ravindran, V.; Cabahug, S.; Ravindran, G.; Bryden, W.L. Influence of microbial phytase on apparent ileal amino acid digestibility of feedstuffs for broilers. Poult Sci 1999, 78, 699-706, https://doi.org/10.1093/ps/78.5.699.

17. Zhang, B.; Rong, Z.Q.; Shi, Y.; Wu, J.G.; Shi, C.H. Prediction of the amino acid composition in brown rice using different sample status by near-infrared reflectance spectroscopy. Food Chem 2011, 127, 275-281, https://doi.org/10.1016/j.foodchem.2010.12.110.

18. Jaskulski, S.; Jung, A.Y.; Rudolph, A.; Johnson, T.; Thöne, K.; Herpel, E.; Sinn, P.; Chang-Claude, J. Genistein and enterolactone in relation to Ki-67 expression and HER2 status in postmenopausal breast cancer patients. Mol Nutr Food Res 2017, 61, 1-10, https://doi.org/10.1002/mnfr.201700449.

19. Li, W.F.; Yang, K.; Zhu, P.; Zhao, H.Q.; Song, Y.H.; Liu, K.C.; Huang, W.F. Genistein ameliorates Ischemia/Reperfusion-Induced renal injury in a SIRT1-Dependent manner. Nutrients 2017, 9, https://doi.org/10.3390/nu9040403.

20. Moore, T.R.; Franks, R.B.; Fox, C. Review of Efficacy of Complementary and Alternative Medicine Treatments for Menopausal Symptoms. J Midwifery Women's 2017, 62, $286-297$. https://doi.org/10.1111/jmwh.12628.

21. Handa, C.L.; De Lima, F.S.; Guelfi, M.F.G.; Da Silva Fernandes, M.; Georgetti, S.R.; Ida, E.I. Parameters of the fermentation of soybean flour by Monascus purpureus or Aspergillus oryzae on the production of bioactive compounds and antioxidant activity. Food Chem 2019, 271, 273-283, https://doi.org/10.1016/j.foodchem.2018.07.188.

22. Kayano, S.I.; Matsumura, Y.; Kitagawa, Y.; Kobayashi, M.; Nagayama A, Kawabata, N.; Kikuzaki, H.; Kitada, Y. Isoflavone C-glycosides isolated from the root of kudzu (Pueraria lobata) and their estrogenic ,activities. Food Chem 2012, 134, 282-287, https://doi.org/10.1016/j.foodchem.2012.02.137.

23. Wang, D.; Zhao, H.; Zhu, H.; Wen, L.; Yu, J.; Li, L.; Chen, L.; Geng, Y. A novel method for highly e ffi cient biotransformation and separation of iso fl avone aglycones from soybean with high-speed countercurrent chromatography. Ind Crop Prod 2019, 129, 224-230, https://doi.org/10.1016/j.indcrop.2018.11.043.

24. Santos, V.A.Q.; Nascimento, C.G.; Schmidt, C.A.P.; Mantovani, D.; Dekker, R.F.H.; Da Cunha, M.A.A. Solid-state fermentation of soybean okara: Isoflavones biotransformation, antioxidant activity and enhancement of nutritional quality. LWT 2018, 92, 509-515, https://doi.org/10.1016/j.lwt.2018.02.067.

25. Chen, L.; Teng, H.; Xiao, J. A value-added cooking process to improve the quality of soybean : Protecting its isoflavones and antioxidant activity. Food Sci Hum Wellness 2019, 8, 195-201, https://doi.org/10.1016/j.fshw.2019.05.001.

26. Rebholz, C.M.; Reynolds, K.; Wofford, M.R.; Chen, J.; Kelly, T.N.; Mei, H.; Whelton, P.K.; He, J. Effect of soybean protein on novel cardiovascular disease risk factors: A randomized controlled trial. Eur. J. Clin. Nutr 2013, 67, 58-63, https://doi.org/10.1038/ejcn.2012.186.

27. Chen, M.; Rao, Y.; Zheng, Y.; Wei, S.; Li, Y.; Guo, T.; Yin, P. Association between soy isoflavone intake and breast cancer risk for pre- and post-menopausal women: A meta-analysis of epidemiological studies. PLoS One 2014, 9, https://doi.org/10.1371/journal.pone.0089288.

28. Ko, K.P.; Kim, S.W.; Ma, S.H.; Park, B.; Ahn, Y.; Lee, J.W.; Lee, M.H.; Kang, E.; Kim, L.S.; Jung, Y.; Cho, Y.U.; Lee, B.; Lin, J.H.; Park, S.K. Dietary intake and breast cancer among carriers and noncarriers of BRCA mutations in the korean hereditary breast cancer study 1-3. Am J Clin Nutr 2013, 98, 1493-1501, 
https://doi.org/10.3945/ajcn.112.057760.

29. Singh, S.; Singh, M.; Puri, D. A review on therapeutic effect of non bio-fermented and bio-fermented product of various herbal drugs in the treatment of gastric ulcer. Letters in Applied NanoBioScience 2020, 9, 2, 10421048, https://doi.org/10.33263/LIANBS92.10421048

30. Tyug, T.S.; Prasad, K.N.; Ismail, A. Antioxidant capacity, phenolics and isoflavones in soybean by-products. Food Chem 2010, 123, 583-589, https://doi.org/10.1016/j.foodchem.2010.04.074.

31. Brand-Williams, W.; Cuvelier, M.E.; Berset, C. Use of a free radical method to evaluate antioxidant activity. LWT - Food Sci Technol 1995, 28, 25-30, https://doi.org/10.1016/S0023-6438(95)80008-5.

32. Swain, T.; Hillis, W.E. The phenolic constituents of Prunus domestica. I.-The quantitative analysis of phenolic constituents. J Sci Food Agric 1959, 10, 63-68, https://doi.org/10.1002/jsfa.2740100110.

33. Miliauskas, G.; Venskutonis, P.R.; Van Beek, T.A. Screening of radical scavenging activity of some medicinal and aromatic plant extracts. Food Chem 2004, 85, 231-237, https://doi.org/10.1016/j.foodchem.2003.05.007.

34. Singleton, V.L.; Rossi, J.A.; Colorimetry of total phenolics with phosphomolybdic-phosphotungstic acid reagents. Am J Enol Vitic, 1965, 16:144-158

35. Kroyer, G.; Hegedus, N.; Evaluation of bioactive properties of pollen extracts as functional dietary food supplement. Innov Food Sci Emerg Technol 2001, 2, 171-174, https://doi.org/10.1016/S14668564(01)00039-X.

36. Minussi, R.C.; Rossi, M.; Bologna, L.; Cordi, L.; Rotilio, D.; Pastore, G.M.; Durán, N.; Phenolic compounds and total antioxidant potential of commercial wines. Food Chem 2003, 82, 409-416, https://doi.org/10.1016/S0308-8146(02)00590-3.

37. Haminiuk, C.W.I.; Plata-Oviedo, M.S.V.; De Mattos, G.; Carpes, S.T.; Branco, I.G. Extraction and quantification of phenolic acids and flavonols from Eugenia pyriformis using different solvents. J Food Sci Technol 2014, 51, 2862-2866. https://doi.org/10.1007/s13197-012-0759-z.

38. Granato, D.; Katayama, F.C.U.; De Castro, I.A. Phenolic composition of South American red wines classified according to their antioxidant activity, retail price and sensory quality. Food Chem 2011, 129, 366-373, https://doi.org/10.1016/j.foodchem.2011.04.085.

39. Reissig, J.L.; Strominger, J.L.; Leloir, L.F. A modified estimation. J Biol Chem 1995, 217, 959-966.

40. Aronson, N.N.; Davidson, E.A. Lysosomal Hyaluronidase from Rat Liver. J Op Bioloqical Chem 1967, 242, 37-440.

41. Kuppusamy, U.R.; Khoo, H.E.; Das, N.P. Structure-activity studies of flavonoids as inhibitors of hyaluronidase. Biochem Pharmacol 1990, 40, 397-401, https://doi.org/10.1016/0006-2952(90)90709-t.

42. Mosmann, T. Rapid colorimetric assay for cellular growth and survival: Application to proliferation and cytotoxicity assays. J Immunol Methods, 1983, 65, 55-63, https://doi.org/10.1016/0022-1759(83)90303-4.

43. Hartanti, A.T.; Rahayu, G.; Hidayat, I. Rhizopus Species from Fresh Tempeh Collected from Several Regions in Indonesia. Hayati J Biosci 2015, 22, 136-142. https://doi.org/10.1016/j.hjb.2015.10.004.

44. Niveditha, V.R.; Sridhar, K.R. Antioxidant activity of raw, cooked and Rhizopus oligosporus fermented beans of Canavalia of coastal sand dunes of Southwest India. J Food Sci Technol 2014, 51, 3253-3260, https://doi.org/10.1007/s13197-012-0830-9.

45. Huang, Y.H.; Lai, Y.J.; Chou, C.C. Fermentation temperature affects the antioxidant activity of the enzymeripened sufu, an oriental traditional fermented product of soybean. J Biosci Bioeng 2011, 112, 49-53, https://doi.org/10.1016/j.jbiosc.2011.03.008.

46. Abu-salem, F.M.; Mohamed, R.K.; Gibriel, A.Y.; Rasmy, N.M.H. Levels of Some Antinutritional Factors in Tempeh Produced From Some Legumes and Jojobas Seeds. Int. Sch. Sci. Res. Innov 2014, 8.

47. Zhang, Z.; Lv, G.; Pan, H.; Fan, L.; Soccol, C.R.; Pandey, A. Production of powerful antioxidant supplements via solid-state fermentation of wheat (Triticum aestivum Linn.) by Cordyceps militaris. Food Technol Biotechnol 2012, 50, 32-39.

48. Hirota, A.; Taki, S.; Kawaii, S.; Yano, M.; Abe, Naoki. 1,1-Diphenyl-2-picrylhydrazyl Radical-scavenging Compounds from Soybean Miso and Antiproliferative Activity of Isoflavones from Soybean Miso toward the Cancer Cell Lines. Biosci Biotechnol Biochem 2005, 64, 1038-1040, https://doi.org/10.1271/bbb.64.1038.

49. Olmos, A.R.; De Garro, M.S. Metabolic pro fi le of Lactobacillus paracasei subsp . paracasei CRL 207 in solid state fermentation using commercial soybean meal. Food Biosci 2020, 35, https://doi.org/10.1016/j.fbio.2020.100584.

50. Alejandra, M.; Deza, C.; Olmos, A.R.; De Garro, M.S. Solid state fermentation to obtain vegetable products bio-enriched with isoflavone aglycones using lactic cultures. Rev Argent Microbiol 2019, 51, 01-207,, https://doi.org/10.1016/j.ram.2018.04.006.

51. Noda, S.; Miyazaki. T.; Miyoshi, T.; Miyake, M.; Okai, N.; Tanaka, T.; Ogino, C.; Kondo, A. Cinnamic acid production using Streptomyces lividans expressing phenylalanine ammonia lyase. J Ind Microbiol Biotechnol 2011, 38, 643-648, https://doi.org/10.1007/s10295-011-0955-2.

52. Benedetti, S.; Prudêncio, E.S.; Nunes, G.L.; Guizoni, K.; Fogaça, L.A.; Petrus, J.C.C. Antioxidant properties of tofu whey concentrate by freeze concentration and nanofiltration processes. J Food Eng 2015, 160, 4955, https://doi.org/10.1016/j.jfoodeng.2015.03.021. 
53. Ram, G.; Sharma, V. R.; Sheikh, I.; Sankhyan, A.; Aggarwal, D. Anti-cancer potential of natural products: recent trends, scope and relevance. Letters in Applied NanoBioScience 2020, 9, 1, 902-907, https://doi.org/10.33263/LIANBS93.11651176.

54. Da Silva, L.H; Celeghini, R.M.S.; Chang, Y.K. Effect of the fermentation of whole soybean flour on the conversion of isoflavones from glycosides to aglycones. Food Chem 2011, 128, 640-644, https://doi.org/10.1016/j.foodchem.2011.03.079.

55. Marazza, J.A.; Nazareno, M.A.; De Giori, G.S.; Garro, M.S. Enhancement of the antioxidant capacity of soymilk by fermentation with Lactobacillus rhamnosus. Journal of functional foods 2012, 4, 594-601, https://doi.org/10.1016/j.jff.2012.03.005.

56. Hong, G.E.; Mandal, P.K.; Lim, K.W.; Lee, C.H. Fermentation Increases Isoflavone Aglycone Contents in Black Soybean Pulp. Asian J Anim Vet Adv 2012, 7, 502-511, http://dx.doi.org/10.3923/ajava.2012.502.511.

57. Izumi, T.; Piskula, M.K.; Osawa, S.; Obata, A.; Tobe, K.; Saito, M.; Kikuchi, M. Soy isoflavone aglycones are absorbed faster and in higher amounts than their glucosides in humans. The Journal of nutrition 2000, 130, 1695-1699, https://doi.org/10.1093/jn/130.7.1695.

58. Lee, J.H.; Hwang, C.E.; Son, K.S.; Cho, K.M. Comparisons of nutritional constituents in soybeans during solid state fermentation times and screening for their glucosidase enzymes and antioxidant properties. Food Chem 2019, 272, 362-371, https://doi.org/10.1016/j.foodchem.2018.08.052.

59. El-Safory, N.S.; Fazary, A.E.; Lee, C.K. Hyaluronidases, a group of glycosidases: Current and future perspectives. Carbohydr Polym 2010, 81, 165-181, https://doi.org/10.1016/j.carbpol.2010.02.047.

60. Girish, K.S.; Kemparaju, K. The magic glue hyaluronan and its eraser hyaluronidase: A biological overview. Life Sci 2007, 80, 1921-1943, https://doi.org/10.1016/j.lfs.2007.02.037.

61. Sgariglia, M.A.; Soberón, J.R.; Poveda, C.A.; Sampietro, D.A.; Vattuone, M.A. Anti-inflammatory properties of phenolic lactones isolated from Caesalpinia paraguariensis stem bark. J Ethnopharmacol 2013, 147, 63-73, https://doi.org/10.1016/j.jep.2012.12.030.

62. Falcão, H.G.; Handa, C.L.; Silva, M.B.R.; De Camargo, A.C.; Shahidi, F.; Kurozawa, L.E.; Ida, E.I. Soybean ultrasound pre-treatment prior to soaking affects $\beta$-glucosidase activity, isoflavone profile and soaking time. Food chemistry 2018, 269, 404-412, https://doi.org/10.1016/j.foodchem.2018.07.028.

63. Fukutake, M.; Takahashi, M.; Ishida, K.; Kawamura, H.; Sugimura, T.; Wakabayashi, K. Quantification of genistein and genistin in soybeans and soybean products. Food Chem Toxicol 1996, 34, 457-461, https://doi.org/10.1016/0278-6915(96)87355-8.

64. Wang, H.J.; Murphy, P.A.; Isoflavone Content in Commercial Soybean Foods. J Agric Food Chem 1994, 42, 1666-1673, https://doi.org/10.1021/jf00044a016.

65. Valério, D.A.; Georgetti, S.R.; Magro, D.A.; Casagrande, R.; Cunha, T.M.; Vicentini, F.T.M.C.; Vieira, S.M.; Fonseca, M.J.V,.; Ferreira, S.H.; Cunha, F.Q.; Verri, W.A. Quercetin Reduces Inflammatory Pain: Inhibition of Oxidative Stress and Cytokine Production. J Nat Prod 2009, 72, 1975-1979, https://doi.org/10.1021/np900259y.

66. González-Montoya, M.; Hernández-Ledesma, B.; Silván, J.M.; Mora-Escobedo, R.; Martínez-Villaluenga, C. Peptides derived from in vitro gastrointestinal digestion of germinated soybean proteins inhibit human colon cancer cells proliferation and inflammation. Food Chem 2018, 242, 75-82, https://doi.org/10.1016/j.foodchem.2017.09.035.

67. Sánchez-Chino, X.; Jiménez-Martínez, C.; Dávila-Ortiz, G.; Álvarez-González, I.; Madrigal-Bujaidar, E. Nutrient and nonnutrient components of legumes, and its chemopreventive activity: A review. Nutr Cancer 2015, 67, 401-410, https://doi.org/10.1080/01635581.2015.1004729.

68. Zhu, B.; Sun, Y.; Qi, L.; Zhong, R.; Miao, X. Dietary legume consumption reduces risk of colorectal cancer: Evidence from a meta-analysis of cohort studies. Sci Rep 2015, 5, 27-33, https://doi.org/10.1038/srep08797.

69. De Mejia, E.G.; Dia, V.P. The role of nutraceutical proteins and peptides in apoptosis, angiogenesis, and metastasis of cancer cells. Cancer Metastasis Rev 2010, 29, 511-528, https://doi.org/10.1007/s10555-0109241-4.

70. Dia, V.P.; De Mejia, E.G. Lunasin induces apoptosis and modifies the expression of genes associated with extracellular matrix and cell adhesion in human metastatic colon cancer cells. Mol Nutr Food Res 2011, 55, 623-634, https://doi.org/10.1002/mnfr.201000419.

71. Tsai, C.Y.; Chen, Y.H.; Chien, Y.W.; Huang, W.H.; Lin, S.H. Effect of soy saponin on the growth of human colon cancer cells. World J Gastroenterol 2010, 16, 3371-3376.

72. Montales, M.T.E.; Simmen, R.C.M.; Ferreira, E.S.; Neves, V.A.; Simmen, F.A. Metformin and soybeanderived bioactive molecules attenuate the expansion of stem cell-like epithelial subpopulation and confer apoptotic sensitivity in human colon cancer cells. Genes Nutr 2015, 10, 1-14, https://doi.org/10.1007/s12263-015-0499-6. 